\title{
Two Symposia on Human- Horticulture Interactions in the 25th International Horticultural Congress in Belgium
}

Eisuke $M$ atsuo

ADDITIONAL INDEX WORDS. human issues in horticulture, human-horticulture relationships, people-plant interaction, sociohorticulture, benefits of plants, human well-being, horticultural therapy

SUMmaRY. In August 1998, there were two symposia concerning human-horticulture relationships held at the International $\mathrm{H}$ orticultural Congress. The speakers at the first symposium introduced many activities that are occurring in this field around the world. The second symposium addressed allotment and community gardens. A brief summary of these symposia is presented.

A $\mathrm{t}$ the 25th International $\mathrm{H}$ orticultural Congress ( $\mathrm{IH} \mathrm{C}$ ) in Brussels, Belgium, in August 1998, two symposia concerned human-horticulture interactions were held. They were " $\mathrm{H} \mathrm{u}$ man-H orticulture Relationships: An International Perspective" and "Allotment and Community Gardening as Part of $\mathrm{U}$ rban H orticulture." Previous symposia on human-horticulture relationships, including "The Role of H orticulture in $\mathrm{H}$ uman Well-being and Social D evelopment" at Arlington, Va., in 1990, and "H orticulture in H uman Life, Culture, and Environment" in Kyoto, Japan, in 1994, have dealt with various aspects of human-horticulture interactions, addressing such issues as the influence of plants and horticulture on human health and well-being, what humans learn through horticulture, using horticulture for education, horticultural influences in different cultures or community development, and the roles of living plants in human daily life and environment. Such symposia have drawn wide attention to human-horticulture relationships among horticulturists in many countries and set the stage for those at the 25th IH C session.

Division of Bioresources and Bioenvironmental Sciences, Graduate School, Kyushu U niversity, Fukuoka-shi 812-8581, J apan. The cost of publishing this paper was defrayed in part by the payment of page charges. U nder postal regulations, this paper therefore must be hereby marked advertisement solely to indicate this fact. 
The goal of the IHC symposium on "H uman-H orticulture R elationships: An International Perspective" was to present an overview and summary of what is happening in research, education, and application of human-horticulture relationships in four regions of the world. The topics were " $\mathrm{H} \mathrm{u}$ man-H orticulture Relationshipsin $\mathrm{N}$ orth and South A merica" (V.I . L ohr, Washington State U niversity, Pullman)," H uman-H orticulture Relationship: Current Situation in Europe in Research, Education, and Application" (A. Evers, $\mathrm{U}$ niversity of $\mathrm{H}$ elsinki, Finland), and "Present Status of $\mathrm{H}$ uman-H orticulture $\mathrm{Re}$ lationships in Asia/ Africa" (E. M atsuo, Kyushu U niversity, Fukuoka-shi, Japan). "Present Status of $\mathrm{H}$ uman-H orticulture Relationships R esearch: Australia, N ew Z eal and and the South Pacific" (D. Aldous, U niversity of M elbourne, Australia). Each of these topics was followed by enthusiastic discussion among the 30 participants. The symposium made the participants feel that studies on human-horticulture relationships are greatly needed to provideenlightenment and exchange of information, especially in developing countries.

The second IH C symposium presented the current status of allotments and community gardening in the world and explored ways to work collaboratively to promote the development of allotments and community gardensin urban areas. Therearemany people, notonly in European countriesbut also Ameri- can and Asian countries, who are interested in allotments and community gardening as part of urban horticulture. H owever, littleisknown about the current status between countries, as there is no effective system for exchange of information.

Thepresentationsin thissession included: "Allotment and Community Gardening in N orth America" (S. Cosgrove, Toronto Food Policy Council, Canada), "Special Community Garden for Old Person in Japan" $(\mathrm{H}$. Konoshima and Y. Kataoka, Shiga U niversity, O tsu, Japan), "J apanese Perspectives of Allotment and Community Gardening" ( $E$. $M$ atsuo, K yushu U niversity, Fukuoka-shi, J apan), "Swedish Perspectives of Allotment and Community Gardening" (S. Sidblad, Swedish Federation of Allotment and L eisure Garden, Stockholm, Sweden), " C hinese Perspectives of Allotment and Community Gardening" (W.S. Zhou, Yangzhou U niversity, Yangzhou, China), and "Aspects of Allotment Gardening Policies in Berlin, Germany Between 1985 and 1995" (G. Groening, $\mathrm{H}$ ochschule der Kuenste Berlin, Berlin). Engaging discussions concerning the different situations of community gardening in each country followed.

In addition to participating in these symposia at the 25th IH C, people with interests in these areas also began making plans for new sessions on human-horticulture relations at the 26 th I H C , scheduled in Toronto, Canada in 2002. 